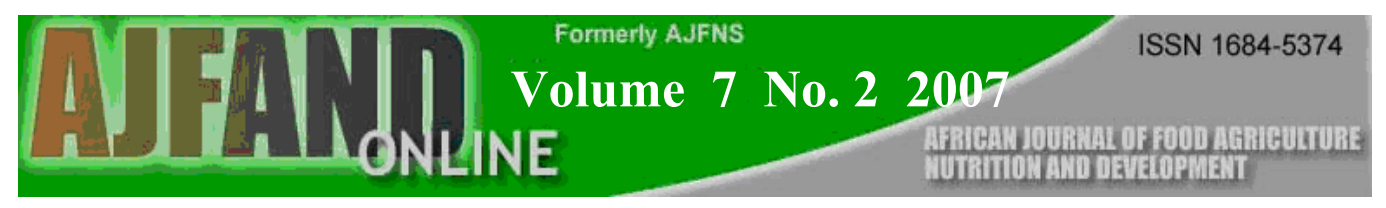

\title{
THE ROLE OF IRRIGATION ON IMPROVEMENT OF NUTRITIONAL STATUS OF YOUNG CHILDREN IN CENTRAL KENYA
}

\section{By}

Kirogo Veronicah $^{1 *}$, Wambui Kogi-Makau ${ }^{2}$, Nelson M. Muroki ${ }^{3}$

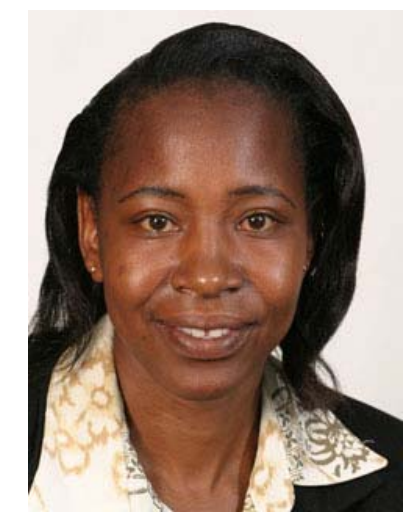

Kirogo Veronicah

${ }^{1 *}$ Corresponding author:- Email vkirogo@yahoo.com

Veronica Kirogo, MSc., BSc., Nutrition Officer, Extension Services Division, Ministry of Agriculture, P.O Box 30028, Nairobi, Kenya;

2* Wambui Kogi-Makau, PhD., Associate Professor and ${ }^{3 *}$ Nelson M. Muroki (Posthumous) PhD, MSH, MSc., BSc., Associate Professor, both of Department of Food Technology and Nutrition, University of Nairobi, P.O. Box 29053, Nairobi, Kenya. 


\begin{abstract}
A comparative, retrospective cross-sectional study was conducted to investigate the role of irrigation on improvement of nutritional status of children aged $6-59$ months in a semi-arid setting. Two equal samples of fifty-nine children (aged $6-59$ months) hereafter, referred to as the Project and the Non-project groups, respectively were randomly selected from households with and without access to irrigation water in Kieni East Division of Nyeri District, Kenya. The study area is situated in the drier western leeward side of Mt. Kenya and is characteristic by unreliable rainfall of between 500 to $1200 \mathrm{~mm}$ per annum.
\end{abstract}

Weight, height and age of index children were determined and the corresponding standard deviations of weight-for-age, weight-for-height and height-for-age calculated and compared to the reference standards developed by the US National Centre for Health Statistics. Energy and nutrient intake was determined using 24-hour dietary recall method. The findings on socio-demographic characteristics showed that the Project and Non-project households were similar in terms of household size, land size, marital status of the respondent, maternal and paternal education and occupation. The calorie intake of over two-fifth $(42 \%)$ of the children from the Non-project households compared to $39 \%$ from the Project households was below the Recommended Daily Allowance.

The children from commercial farming Project households had significantly higher weight-for-age Z-score than those from commercial farming Non-project households. Similarly, children from high-income Project households had significantly higher height-for-age Z-score than those from high-income Non-project households. The prevalence of stunting was also significantly lower in the high-income Project households compared to high-income Non-project households. Among the male children, the prevalence of underweight was significantly higher in Non-project households than in Project households. Overall, the prevalence of stunting and underweight which are indicators of long-term nutritional deprivation were higher in Non-project households than Project households. The findings of the study led to the conclusion that irrigation contributes to increased per capita food availability resulting in higher energy intakes and subsequently enables households to safeguard young children against chronic malnutrition. Also, poverty as characterised by low household income remains a main determinant of nutritional status.

Keywords: stunting; wasting; underweight; irrigation

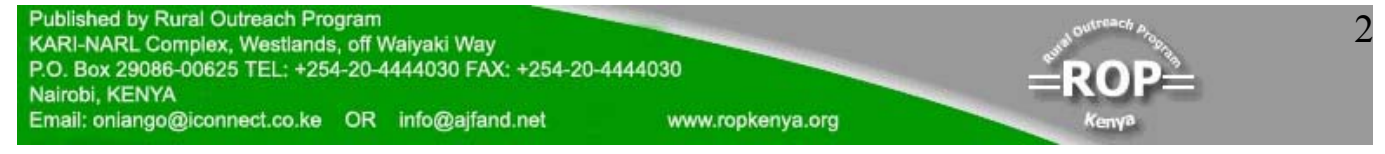




\section{INTRODUCTION}

Irrigation is a major input in increasing crop yields especially in areas with good quality soils, whose expected outcome is either increased household income and/or improved household food availability. In households where the resultant increase in yields or income is used to meet the dietary needs, improved nutritional status is expected.

Prevalence of malnutrition among 6-59 months age group is usually used as an indicator for nutritional status of the entire population, because this sub-group is more sensitive to nutritional stress. In developing countries, stunting affects about a third of the children below five years of age. In Africa, the prevalence of underweight and wasting has been reported to be $29.1 \%$ and $9.6 \%$ respectively. The highest levels of stunting are observed in eastern Africa; where on average 48.1 percent of pre-school children are affected [1].

In Kenya, the prevalence of stunting, wasting and underweight, according to the 1998 Demographic Health Survey (KDHS), was 33\%, 6\% and 22\% respectively [2]. The situation has since slightly improved by dropping to a prevalence of $30 \%$ and $20 \%$ in stunting and underweight, respectively, as shown by the 2003 KDHS [3]. Although Central Province, where the study area is located has a lower prevalence $(28 \%$ stunted; $6 \%$ wasted and $14 \%$ underweight) than the national figure, the parameters for the study area are expected to be worse. Kieni East is an arid land within a high potential region; that is characterised by erratic rainfall pattern [4]. No data was available on the prevalence of malnutrition in the semi-arid and arid areas in the district hence the object of this study was to establish the prevalence and investigate the role of irrigation on improvement of nutritional status of children aged $6-59$ months in a semi-arid setting that is juxtaposed in a high potential region.

\section{MATERIALS AND METHODS}

The study area, Kieni East is one of the seven divisions in Nyeri District covering an area of $727 \mathrm{~km}^{2}(22 \%$ of the total district area) and is situated in the drier western leeward side of Mt. Kenya. The area, whose daily average temperature range of between $16-27{ }^{\circ} \mathrm{C}$ lies between 2130 and 2400 metres above sea level while its hill soils are of moderate to high fertility. However, aridity hinders full exploitation of its innate agriculture potential. The rainfall, which varies with altitude, ranges between $500-1200 \mathrm{~mm}$ rising to over $2000 \mathrm{~mm}$ in the upper areas while its pattern is erratic and is characterised by heavy showers and storms that sometimes cause severe erosion and considerable crop damage.

According to the 1999 Kenya Population and Housing Census, the study area is home to 83,635 people who are distributed within 21,738 households [5], that implies an average of four people per household.

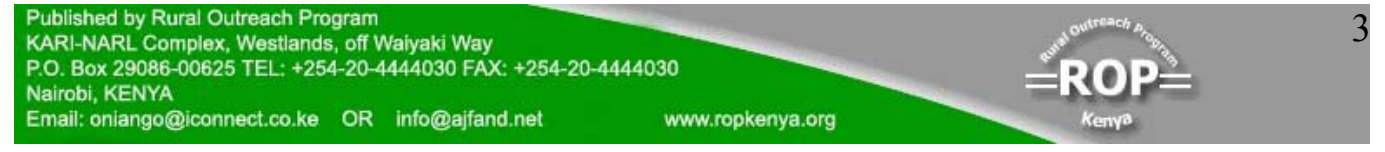


Slightly less than a third of the households (30\%) grow high value cash crops, such as, pyrethrum and horticultural crops and $40 \%$ grow high value food crops such as maize, beans, and Irish potatoes. The area relies heavily on irrigation water for horticultural production. Through the assistance of the Nyeri Dry Area Smallholder Community Services Development Project (NDAP), 16 irrigation schemes have been established out of which five namely, Kambura-ini, Gitwe, Kirinyaga-Nyange, Narumoro-Aguthi and Waraza/Lusoi have been operational for at least five years.

\section{Research Design}

A comparative, retrospective cross-sectional design that was also descriptive and analytical in nature was employed to compare nutritional status of children in households with and without access to irrigation water.

\section{Sampling Procedure}

A multistage sampling model was employed. The Nyeri Dry Area Smallholder Community Services Development Project (NDAP) funded the implementation of most of the water projects in the study area and hence the purposive selection of Kieni East division. Out of the total sixteen water projects that are funded by the NDAP, only five qualified to be included in the study after satisfying the selection criteria (having been in operation for at least five years). From these five, three projects, namely Kambura-ini, Waraza-Lusoi and Narumoro-Aguthi were randomly chosen through lottery.

A list of all households, which also indicated whether or not they were connected to irrigation water supply, constituted the sampling frame comprising of 385 project households and 136 non-project households. From the list, 59 Non-project households satisfied the selection criteria of having at least one child aged between $6-59$ months and being practising farmers. Subsequently, an equal number of project households (59) were randomly sampled using predetermined sampling interval, after meeting the selection criteria. The sampling interval was obtained by dividing the total number of households in each area by the number of households to be sampled per village.

\section{Estimation of Dietary Intake}

Energy and nutrient intake was determined using the 24-hour recall method as described by Lee and Nieman [6]. In this method, the mother of the index child or the person who prepared the meals were asked to describe all the dishes that were prepared for the child during the past 24 hours, as well as the ingredients that were used for each dish.

The person was then asked to use the same utensils as in the previous day and pour in water to a level equivalent to that the amount of ingredients used reached. The water was then measured using a calibrated jug and readings recorded in millilitres ( $\mathrm{ml}$ ). Similarly, the amounts served to the index child as well as any leftovers were recorded. The amount of leftovers was deducted from the original serving and the child's portion recorded in $\mathrm{ml}$.

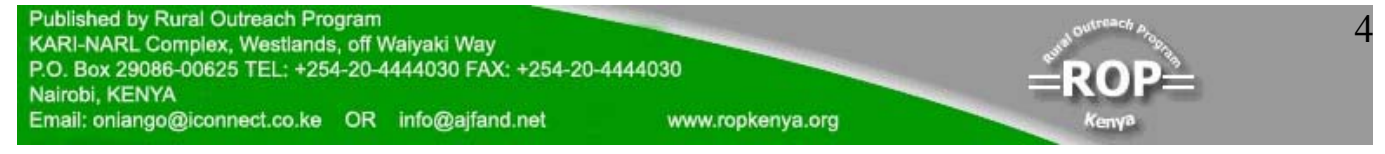


The measurements were then converted into estimated equivalent grams of food using respective conversion factors [7]. The nutritive value of all the ingredients used in the preparation of the different dishes and for all the foods consumed by the index child was determined based on the national food composition tables developed for Kenya [8]. The nutrients of interest were energy, protein, iron and vitamin A. The index children's intakes were then compared to the recommended dietary allowance (RDA) for Kenya for children of the same age group in order to determine the level of intake in relation to the RDA.

To determine the total energy available to the household per day, the calories in all the food prepared for the family were standardized by converting into equivalent consumer unit $(\mathrm{CU})$ where one $\mathrm{CU}$ is equivalent to an energy standard reference by World Health Organization (WHO) of 2960 kilocalories per adult equivalent. The energy requirements of individuals in each household were expressed as a ratio of the reference and the total requirements for each household calculated in terms of CU. The total CU available to the household was then expressed as a ratio of the total required $\mathrm{CU}$ to obtain the household dietary energy adequacy ratio (HDEAR).

\section{ANTHROPOMETRIC MEASUREMENTS}

\section{Weight}

Weight was measured using salter scales and recorded to the nearest $0.1 \mathrm{~kg}$ as recommended by the World Health Organization (WHO) [9]. Prior to each weighing, the pointer was adjusted to zero as a way of enhancing validity. In observance of the rights of the child, the children were weighed in light clothing rather than in the nude. A correction for the clothing was made during data analysis by subtracting 150 grams from each child's weight. This weight of clothing was estimated by determining the mean weights of light clothes worn by children of the different age groups that were represented in the survey. To further enhance the accuracy and the reliability of weight measurements, the reading was done when the child was stably hanging on the scale at a point when the pointer was not wobbling, the eye was in a horizontal position with the weighing scale as the reading was done and was recorded immediately.

\section{Length/Height}

Following the WHO recommended height measuring techniques, recumbent and vertical height of, respectively, the children below two years of age and those above was taken using a standardized measuring board that had a fixed head rest and a movable foot piece $[9,10]$. To enhance the validity of measurements, care was taken to maintain the child's head in an upright position, the body well stretched with the back firmly on the board, the legs stretched to a full extent and feet (without shoes) at right angles with legs. The length/height measurements were recorded to the nearest $0.1 \mathrm{~cm}$.

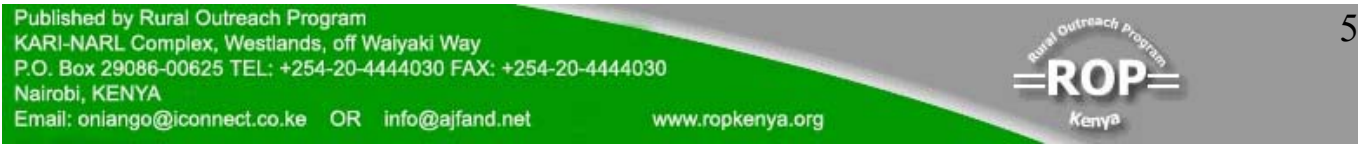




\section{Data Entry and Analysis}

ISSA-X computer package and STATA for Windows version 6.0, respectively were used for data entry and cleaning and all the detected inconsistencies were addressed. In addition, standard tabulations were generated in which the outliers were identified prior to subjecting the data to analyses. Conversion of anthropometric measurements into indices of nutritional status (height-for-age, weight-for-age and weight-forheight) was done using EPI-INFO, which has the capacity of identifying unrealistic values through its inherent validity check for enhanced data quality control. No measurements, however, were found to be invalid among the three nutritional indices. The statistical t-tests and chi-square were used to test the differences between different parameters and between the Project and the Non-project groups. A p-value of below 0.05 denoted significance in differences.

\section{RESULTS}

The findings on socio-demographic characteristics of the survey households showed that the two sets of households were similar in terms of household size, marital status of the respondent, maternal and paternal education and occupation. There was no significant difference in the average household size, although Project households had slightly smaller households (mean 5.0) than Non-project households, which were 5.2. Most of the respondents (90\% in the Project households and $86 \%$ in Non-project households) were married. About half of the mothers of the index children (49\% from the Project households and 55\% from Non-project households) had completed 5 - 8 years of primary education. There was no significant difference in the land size, although the average land size of non-project households ( 2.3 acres) was bigger than that of the project households (2.1 acres). A total of 118 children (32 males and 27 females from the project households; and 30 males and 29 females from Non-project households) had their anthropometric measurements taken.

\section{Food Production}

Data on yields per acre is presented in Figure 1. There were no significant differences in the yields per acre of beans and potatoes in the two areas, although the project households harvested beans about double the amount harvested by non-project households. However, maize yields were significantly higher in the project households than in non-project households $(p=0.05)$.

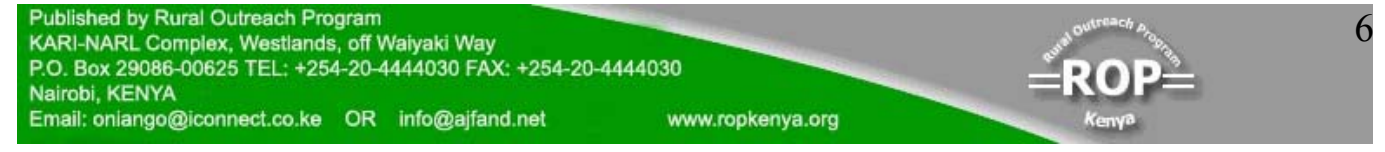


Figure 1 Average Yields per Acre

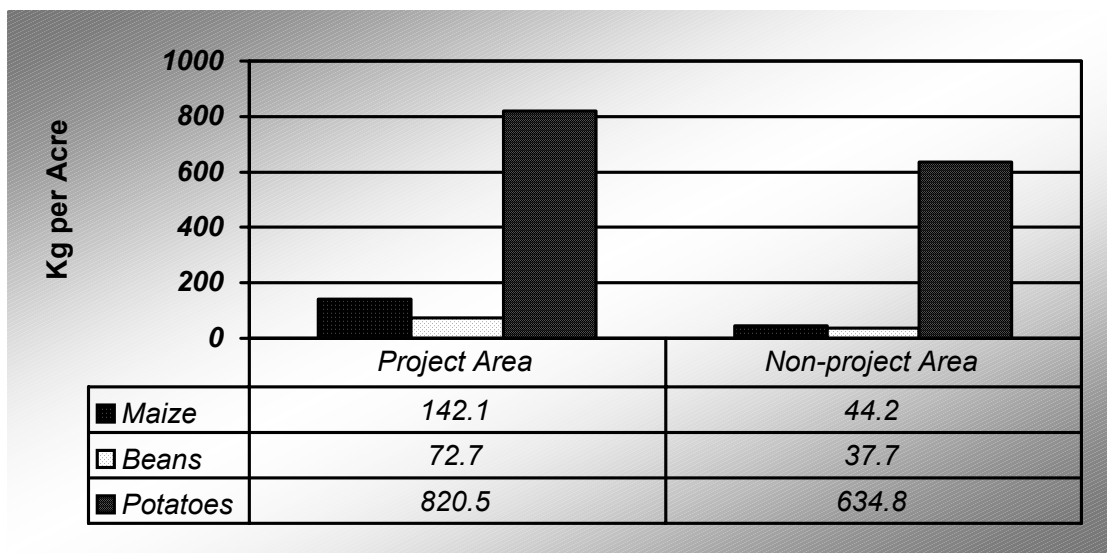

\section{Dietary Intake}

The children whose mean daily energy and protein intake is presented in Figures 2 and 3 were categorized into three age groups. On average, all the children had higher than the recommended energy and protein intakes except for children $(12-23$ months) from Non-project households, whose energy intake was below the RDA. The mean energy and protein intake of children $(24-35$ and $35-59$ months age group) from Non-project households were higher than those of children from Project households. However, the differences were not significant.

Figure 2 Mean Energy Intake by Age Group
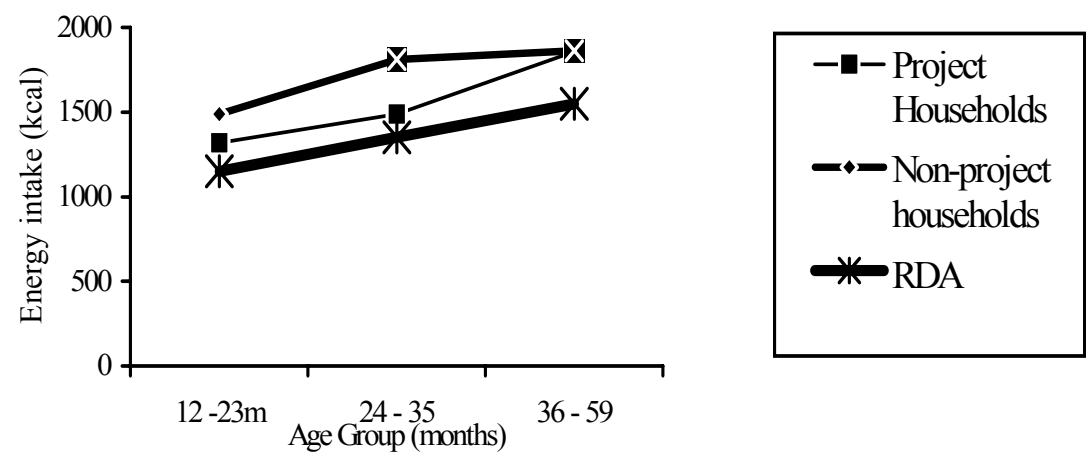
Figure 3 Mean Protein Intake by Age Group
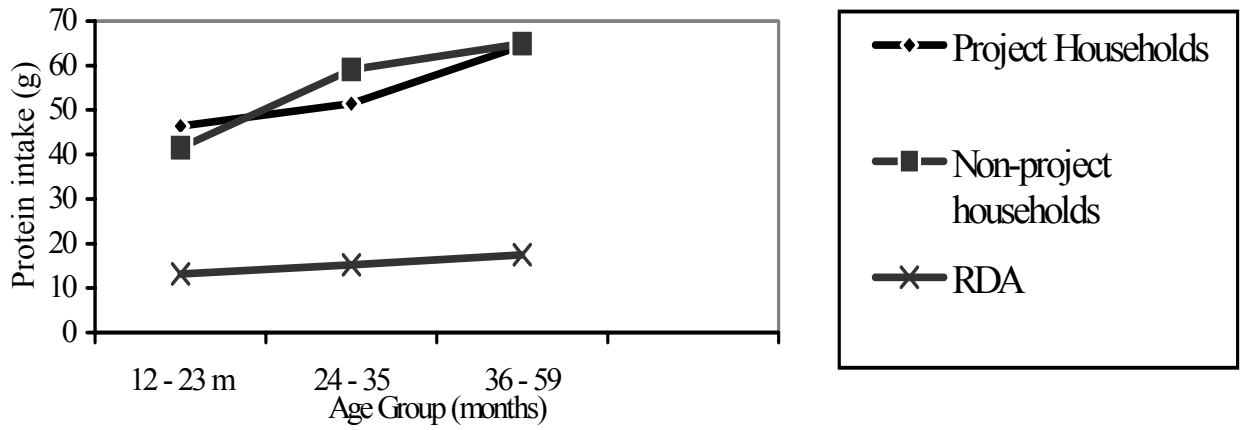

Slightly more than two fifths $(42 \%)$ of the children from non-project households who were under five years of age compared to $39 \%$ of the children from the project households had energy intake that was below the RDA (Figure 4).

Figure 4 Percent Children Aged 6-59 Months with Energy and Nutrient Intake Below RDA

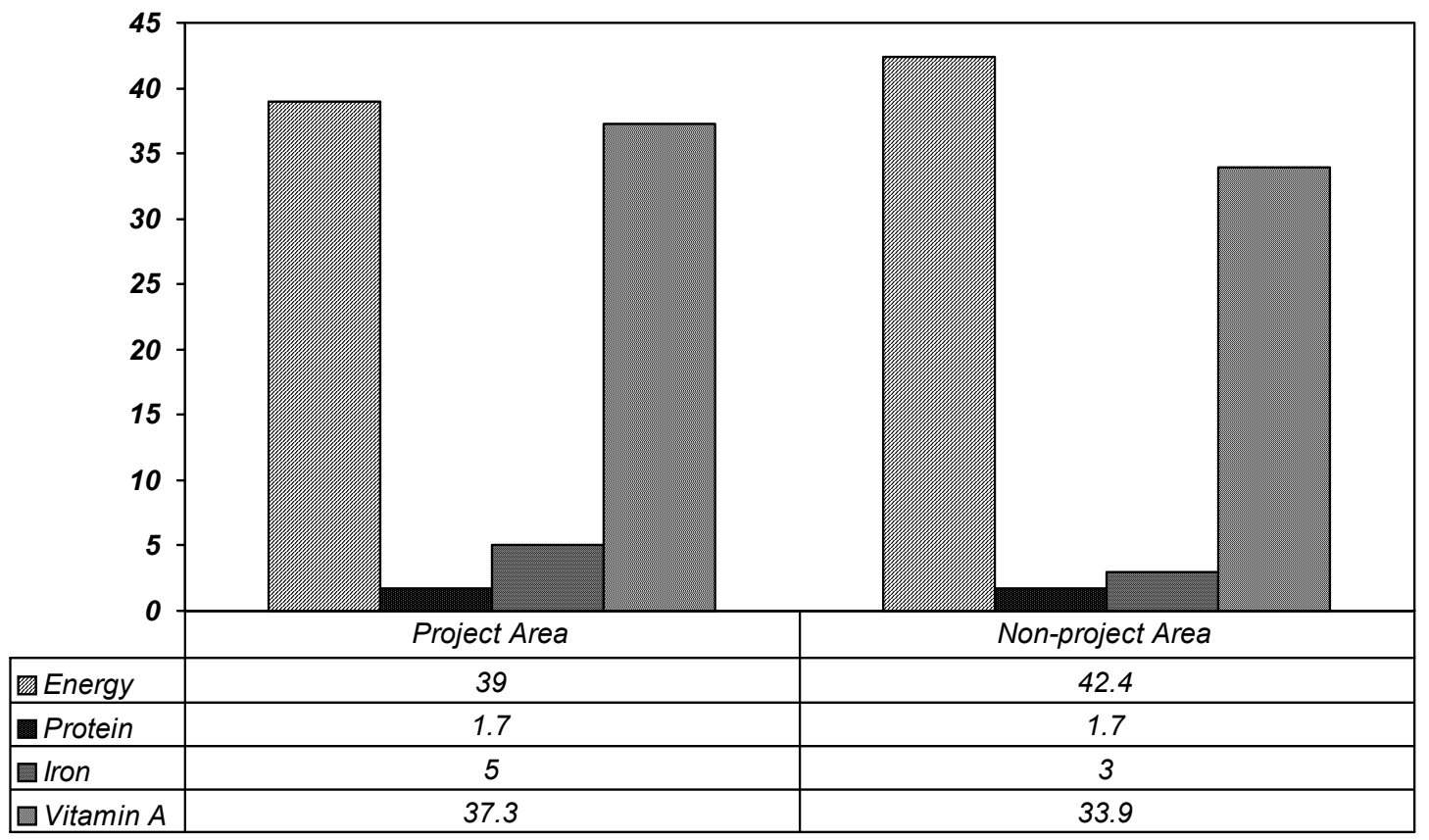

Nutritional Status of Children 6 - 59 months

Although the data on Table 1 show that on average, the children from the project households had higher mean height-for-age (HAZ), weight-for-height (WHZ) and weight-for-age (WAZ), the differences were not significant. When the study 
households were categorised by type of farming, the children from commercial farming households in the project area had significantly higher mean WAZ $(\mathrm{P}<0.05)$. Also, the children from the project households whose income was above the rural poverty line for Kenya had significantly higher mean HAZ than those from nonproject households $(\mathrm{P}<0.05)$. The male children from the project households had higher mean HAZ, WAZ and WHZ than their counterparts in non-project households. Irrespective of land sizes, children from Project households had better mean Z-scores suggesting that irrigation could have some influence on the nutritional status though not significant.

As illustrated in Figure 5, the prevalence of stunting and underweight, which are indicators of long-term nutritional deprivation, were higher in non-project households than in the project households but the difference was not significant.

Figure 5 Prevalence of Stunting, Wasting and Under-weight

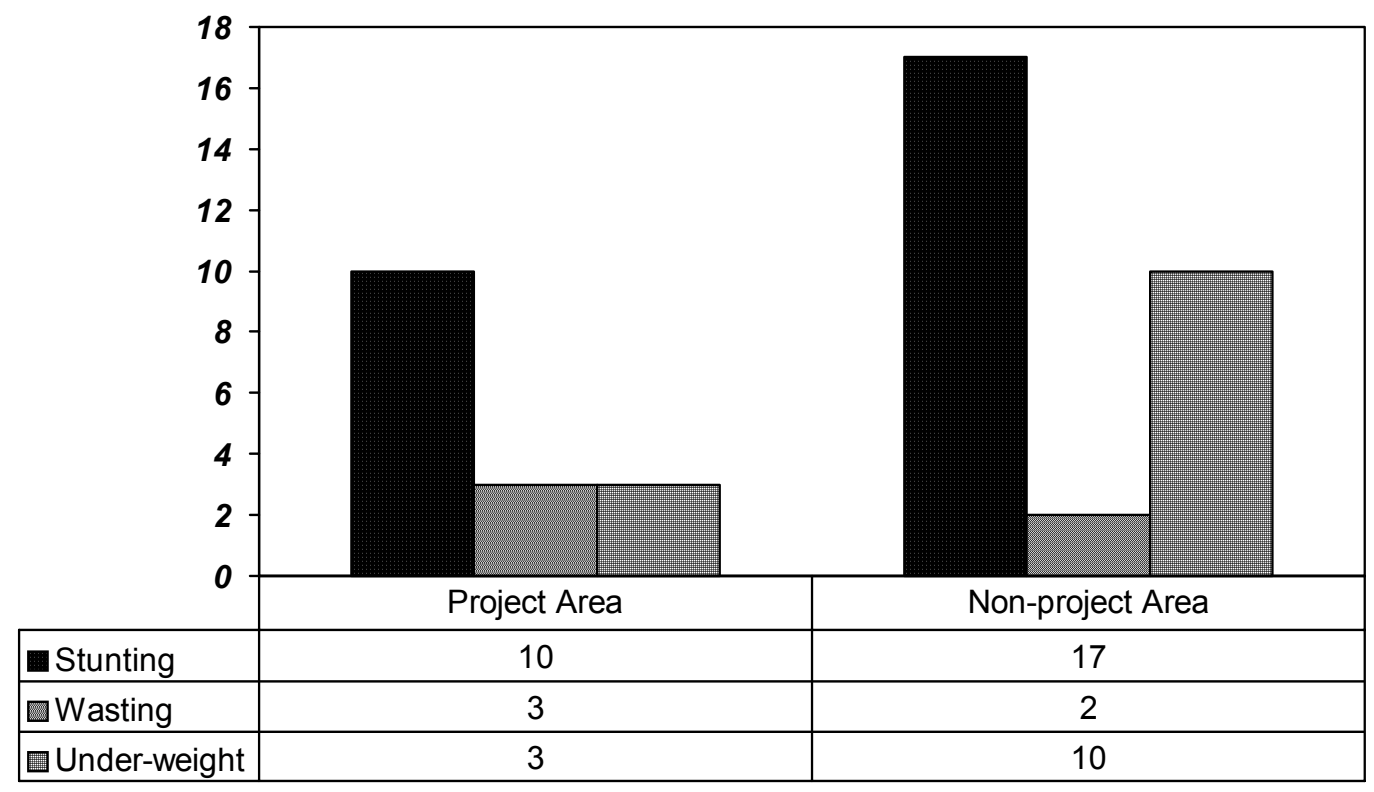

As shown in Table 2, a slightly higher percentage of children from non-project commercial farming households were stunted. Also, the prevalence of stunting was significantly lower in the higher-income project households than in the Non-project households of the same income group $(\mathrm{P}<0.02)$. Although there was no significant difference in the proportion of children who were underweight, it was slightly lower among the project children when compared with the non-project ones. 
Nevertheless, the prevalence of underweight among the male children from the nonproject households was significantly higher $(\mathrm{P}<0.03)$ than among the project ones. Although the difference was not significant the proportion of children who were underweight was slightly lower in the project households as per selected variables Table 3).

\section{DISCUSSION}

The findings of this study indicate that the average calorie and nutrient intake of children under five years of age were above the RDA. However, the mean energy intake of children (12 - 35 months) from non-project households was lower than the RDA. This could probably be due to the fact that, in most households, children of this age are commonly fed from the family dish, which may not provide them with adequate calories. Moreover, family dish comprised of a mixture of maize, beans and occasionally potatoes, which although containing energy and micronutrients, it is high in bulk that, is not only of poor digestibility but is also highly unpalatable to children in this age group. Furthermore young children with limited stomach capacity are unable to consume sufficient quantities of such food to meet their energy and nutrient requirements.

This study established that a higher proportion of children from project households met the RDA of calories implying that irrigation has some influence on dietary energy intake, although there was no significant difference. It is important to note that the study area experienced drought during the reference year that adversely affected household food availability and this could have resulted in low calorie intake. It can also be argued that project households could not realize good yields of horticultural crops due to unreliability of irrigation water and therefore had limited economic returns. Subsequently less income was available to purchase food in order to offset food inadequacy for family at this time.

The study found out that the prevalence of stunting, which is a long-term measure of nutritional status was higher in non-project households while the proportion of children who were wasted was higher in the project households, concurring with findings by Matsvimbo [11]. This indicates that fewer children in project household suffer from chronic malnutrition, which suggests that irrigation has some influence on the nutritional status of children in the long run. When study households were categorized by type of farming, the prevalence of stunting and underweight were lower among children from commercial farming households than non-commercial farming households. There were no significant differences between type of farming and nutritional status. Kennedy and Cogill observed similar findings in a study on nutritional effects of the commercialization of agriculture in South-Western Kenya [12].

The link of access to land and nutritional status is well established, with prevalence of stunting and underweight being higher among children of landless households than children of landed households [13, 14, 15].

Published by Rural Outreach Program
KARI-NARL Complex, Westlands, off Waiyaki Way
P.O. Box 29086-00625 TEL: +254-20-4444030 FAX $+254-20-4444030$
Nairobi, KENYA
Email: oniango@iconnect.co.ke OR info@ajfand.net $\quad$ www.ropkenya.org


In this study, the prevalence of wasting, stunting and underweight was higher among children from households with less land. Also, the average Z-scores of all the three nutritional indicators were lower in households with less land. The importance of irrigation on improvement of nutritional status is once again noted in that irrespective of land size, children from project households had better Z-scores.

The study established that the prevalence of wasting was significantly higher in lowincome households. This supports the findings by Martorell that low-income smallholder households have the highest incidence of malnutrition because lowincome levels limit the kinds and amount of food available for consumption by households [16]. Alderman and Garcia also established that malnutrition in children was more severe in households with lower average per capita income [17]. This is in line with the findings of this study that the prevalence of wasting, stunting and underweight was higher in households with income below poverty line. According to the 2000 Kenya Economic Survey, households with income below the poverty line are unable to access the minimum requirement of food and essential non-food commodities [18]. The influence of irrigation on nutritional status is evident from the fact that children from higher-income project households had significantly higher $\mathrm{HAZ}$ and also the prevalence of stunting was significantly lower

When levels of income categorized study households, children from higher-income project households had significantly higher HAZ and also the prevalence of stunting was significantly lower. Since the households are in the same income group and hence had similar purchasing power it appears that there could be factor(s) other than income that affected nutritional status. The most probable factor could have been the higher food production levels in project households that could have resulted in high per capita food availability and subsequently improved nutritional status. Smith and Haddad identified low per capita food availability as one of the factors associated with child under nutrition in Sub-Saharan Africa [19].

\section{CONCLUSION}

Although the findings of this study have not allowed a definite conclusion to be drawn regarding the role of irrigation on the nutritional status of young children, they have, nevertheless clarified that irrigation enables households to safeguard young children against chronic malnutrition. Irrigation facilitates higher energy intake because it creates synergy, with other household factors, whose impact moderately enhanced household food and nutrition security. Thirdly, poverty as characterised by low household income, remains a main determinant of nutritional status.

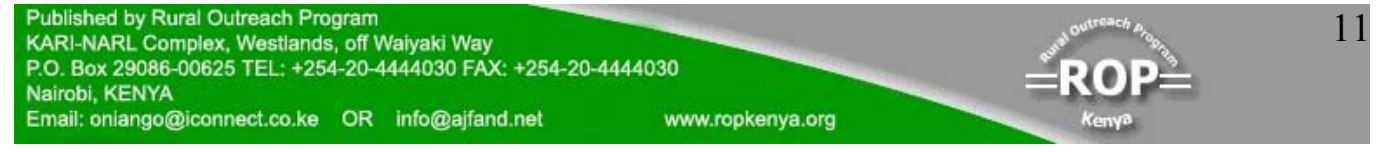




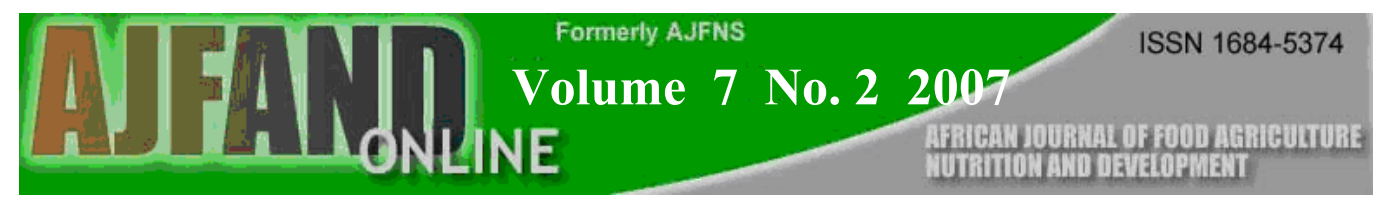

\section{ACKNOWLEDGEMENT}

The authors acknowledge financial support from the Embassy of Belgium and technical support provided by the University of Nairobi. This paper is part of thesis submitted for degree of Master of Science in Applied Human Nutrition. 


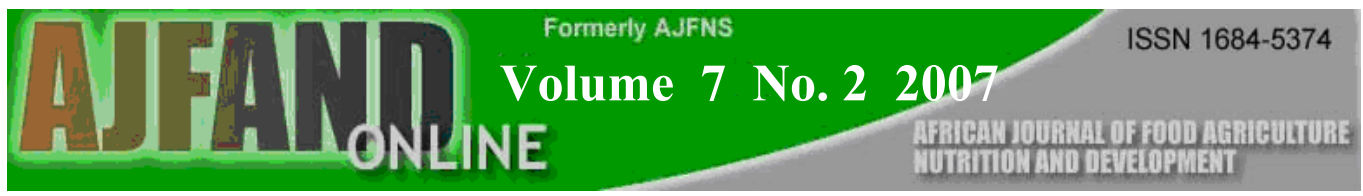

Table 1: Mean Z-scores by Area, Type of Farming, Income Level, Sex of Index Child and Land Size

\begin{tabular}{|c|c|c|c|c|c|c|}
\hline \multirow{2}{*}{ Variable } & \multicolumn{2}{|l|}{ HAZ } & \multicolumn{2}{|l|}{ WAZ } & \multicolumn{2}{|l|}{ WHZ } \\
\hline & Project & NP & Project & NP & Project & $\mathbf{N P}$ \\
\hline Household & -0.65 & $\begin{array}{r}-0.99 \\
(14)\end{array}$ & -0.43 & $\begin{array}{l}-0.7 \\
(12)\end{array}$ & 0.05 & -0.01 \\
\hline \multicolumn{7}{|l|}{ Type of Farming } \\
\hline Commercial & $\begin{array}{l}-0.73 \\
(1.4)\end{array}$ & $\begin{array}{l}-1.0 \\
(1.2)\end{array}$ & $\begin{array}{c}-0.42^{\mathrm{a}} \\
(1.2)\end{array}$ & $\begin{array}{r}-1.03 \\
(0.9)\end{array}$ & $\begin{array}{l}0.11 \\
(1.1)\end{array}$ & $\begin{array}{l}-0.45 \\
(0.9)\end{array}$ \\
\hline Non-commercial & $\begin{array}{l}-0.5 \\
(1.3)\end{array}$ & $\begin{array}{r}-0.99 \\
(1.5)\end{array}$ & $\begin{array}{l}-0.45 \\
(0.8)\end{array}$ & $\begin{array}{l}-0.55 \\
(1.3)\end{array}$ & $\begin{array}{l}-0.07 \\
(0.7)\end{array}$ & $\begin{array}{c}0.19 \\
(1.3)\end{array}$ \\
\hline \multicolumn{7}{|l|}{ Income Level } \\
\hline Below KSh.1240 & $\begin{array}{l}-0.93 \\
(1.5)\end{array}$ & $\begin{array}{r}-0.13 \\
(1.8)\end{array}$ & $\begin{array}{l}-0.68 \\
(1.0)\end{array}$ & $\begin{array}{l}-0.67 \\
(1.5)\end{array}$ & $\begin{array}{l}-0.06 \\
(1.0)\end{array}$ & $\begin{array}{c}-0.63 \\
(1.1)\end{array}$ \\
\hline Above or Equal to KSh.1240 & $\begin{array}{l}-0.59^{b} \\
(1.3)\end{array}$ & $\begin{array}{l}-1.2 \\
(1.2)\end{array}$ & $\begin{array}{l}-0.37 \\
(1.1)\end{array}$ & $\begin{array}{r}-0.72 \\
(1.1)\end{array}$ & $\begin{array}{l}0.08 \\
(1.0)\end{array}$ & $\begin{array}{c}0.12 \\
(1.1)\end{array}$ \\
\hline \multicolumn{7}{|l|}{ Sex of Index Child } \\
\hline Male & $\begin{array}{l}-0.7 \\
(1.2)\end{array}$ & $\begin{array}{l}-1.0 \\
(1.0)\end{array}$ & $\begin{array}{l}-0.3 \\
(1.0)\end{array}$ & $\begin{array}{l}-0.83 \\
(0.9)\end{array}$ & $\begin{array}{l}0.19 \\
(1.1)\end{array}$ & $\begin{array}{r}-0.24 \\
(0.8)\end{array}$ \\
\hline Female & $\begin{array}{l}-0.6 \\
(1.5)\end{array}$ & $\begin{array}{c}-0.97 \\
(1.8)\end{array}$ & $\begin{array}{l}-0.59 \\
(1.1)\end{array}$ & $\begin{array}{l}-0.57 \\
(1.4)\end{array}$ & $\begin{array}{l}-0.11 \\
(0.9)\end{array}$ & $\begin{array}{c}0.24 \\
(1.6)\end{array}$ \\
\hline \multicolumn{7}{|l|}{ Land Size } \\
\hline Less or Equal to 3 acres & $\begin{array}{l}-0.69 \\
(1.4)\end{array}$ & $\begin{array}{l}-1.1 \\
(1.4)\end{array}$ & $\begin{array}{l}-0.5 \\
(1.1)\end{array}$ & $\begin{array}{l}-0.8 \\
(1.2)\end{array}$ & $\begin{array}{l}0.02 \\
(1.0)\end{array}$ & $\begin{array}{c}-0.001 \\
(1.3)\end{array}$ \\
\hline More than 3 acres & $\begin{array}{l}-0.4 \\
(0.8)\end{array}$ & $\begin{array}{l}-0.5 \\
(1.4)\end{array}$ & $\begin{array}{l}-0.1 \\
(0.9)\end{array}$ & $\begin{array}{l}-0.4 \\
(1.3)\end{array}$ & $\begin{array}{l}0.22 \\
(0.8)\end{array}$ & $\begin{array}{r}-0.02 \\
(0.9)\end{array}$ \\
\hline \multicolumn{7}{|c|}{$\begin{array}{l}\text { Notes: } \\
\text { Statistical t-tests are used to compare the difference in mean z scores between the two areas. } \\
\text { The numbers in parentheses are standard deviation. } \\
\text { a p-value }=0.05 \text {. } \\
\text { b } \text { p-value }=0.04 .\end{array}$} \\
\hline
\end{tabular}




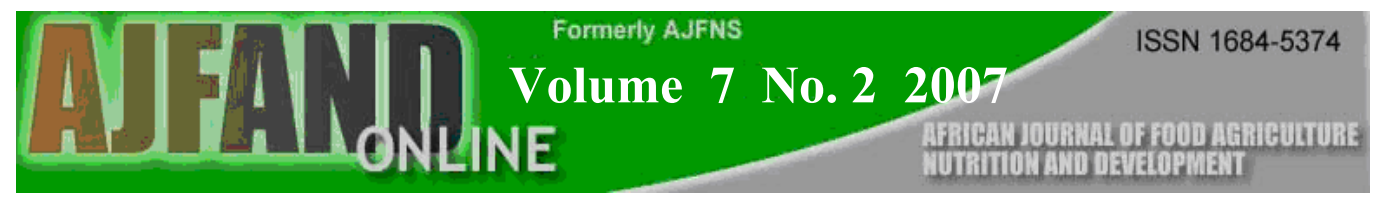

Table 2: Prevalence (\%) of Stunting and Underweight by Area and Selected Variables

\begin{tabular}{|c|c|c|c|c|c|c|}
\hline \multirow[t]{2}{*}{ Variable } & Project HH & $\begin{array}{l}\text { Non- } \\
\text { project HH }\end{array}$ & \multirow[t]{2}{*}{ p-value } & \multirow{2}{*}{$\begin{array}{l}\text { Project } \\
\text { HH } \\
\text { WAZ }<- \\
2.0\end{array}$} & \multirow{2}{*}{$\begin{array}{l}\text { Non-project } \\
\text { HH } \\
\text { WAZ }<~-~ \\
2.0\end{array}$} & \multirow[t]{2}{*}{ p-value } \\
\hline & HAZ $<-2.0$ & HAZ $<-2.0$ & & & & \\
\hline $\begin{array}{l}\text { Type of Farming } \\
\text { Commercial } \\
\text { Non-commercial }\end{array}$ & $\begin{array}{c}8 \\
15\end{array}$ & $\begin{array}{l}22 \\
15\end{array}$ & $\begin{array}{l}0.1 \\
1.0\end{array}$ & $\begin{array}{l}3 \\
5\end{array}$ & $\begin{array}{l}11 \\
10\end{array}$ & $\begin{array}{l}0.2 \\
0.5\end{array}$ \\
\hline $\begin{array}{l}\text { Sex of Child } \\
\text { Male } \\
\text { Female } \\
\end{array}$ & $\begin{array}{c}9 \\
11 \\
\end{array}$ & $\begin{array}{l}13 \\
21 \\
\end{array}$ & $\begin{array}{l}0.6 \\
0.3 \\
\end{array}$ & $\begin{array}{l}0 \\
7 \\
\end{array}$ & $\begin{array}{c}13 \\
7 \\
\end{array}$ & $\begin{array}{c}0.03 \\
0.9 \\
\end{array}$ \\
\hline $\begin{array}{l}\text { Head of Household } \\
\text { Male } \\
\text { Female }\end{array}$ & $\begin{array}{c}9 \\
33 \\
\end{array}$ & $\begin{array}{l}15 \\
29 \\
\end{array}$ & $\begin{array}{l}0.3 \\
0.9\end{array}$ & $\begin{array}{l}4 \\
0 \\
\end{array}$ & $\begin{array}{c}8 \\
29 \\
\end{array}$ & $\begin{array}{l}0.4 \\
0.3 \\
\end{array}$ \\
\hline $\begin{array}{l}\text { Land Size } \\
\text { Less or equal to } 3 \text { acres } \\
\text { More than } 3 \text { acres }\end{array}$ & $\begin{array}{c}12 \\
0 \\
\end{array}$ & $\begin{array}{c}20 \\
8 \\
\end{array}$ & $\begin{array}{l}0.3 \\
0.4\end{array}$ & $\begin{array}{l}4 \\
0\end{array}$ & $\begin{array}{c}11 \\
8 \\
\end{array}$ & $\begin{array}{l}0.2 \\
0.4 \\
\end{array}$ \\
\hline $\begin{array}{l}\text { Income Level } \\
\text { Below Poverty Line } \\
\text { Above Poverty Line }\end{array}$ & $\begin{array}{c}36 \\
4\end{array}$ & $\begin{array}{c}0 \\
20\end{array}$ & $\begin{array}{l}0.02 \\
0.02\end{array}$ & $\begin{array}{l}9 \\
2\end{array}$ & $\begin{array}{c}14 \\
9\end{array}$ & $\begin{array}{l}0.7 \\
0.1\end{array}$ \\
\hline
\end{tabular}

\section{Notes}

$\mathrm{HH}$ refers to household

HAZ refers to Z-score for height-for-age

$\mathrm{WAZ}$ refers to $Z$-score for weight-for-age 


\section{REFERENCES}

1. ACC / SCN The Fourth Report on the World Situation. United Nations Administrative Committee on Co-ordination and Sub-committee on Nutrition, Geneva. 2000: 1 - 20.

2. National Council for Population Development (NCPD), Central Bureau of Statistics (CBS) (Office of the Vice president and Ministry of planning and National Development) [Kenya], and Macro International Inc. (MI) Kenya Demographic and Health Survey 1998. Claverton, Maryland. 1999: 115 -124 .

3. Central Bureau of Statistics (CBS), Ministry of Health (MOH), and ORC Macro Kenya Demographic and Health Survey 2003. Calverton, Maryland. 2004: $153-169$.

4. Government of Kenya Nyeri District Development Plan, 1997-2001. Government Printers, Nairobi. 1997: 1 - 15; 41-66.

5. Government of Kenya The 1999 Population and Housing Census Volume 1, Government Printers, Nairobi. 2001: 1-17.

6. Lee RD and DC Nieman Nutritional Assessment. Mosby-Year book Inc. St. Louis, Missouri, USA. 1996: 91 - 145.

7. King FS and A Burgess Nutrition for Developing Countries, Oxford University Press. 1993: $165-188 ; 433-443$.

8. Sehmi JK National Food Composition Tables and the Planning of Satisfactory Diets in Kenya, Government Printers, Nairobi. 1993.

9. WHO Measuring Change in Nutritional Status; Guidelines for Assessing the Nutritional Impact of Supplementary Feeding Programmes for Vulnerable Groups. WHO, Switzerland. 1983: 12-13.

10. UN How to Weigh and Measure Children: Assessing the Nutritional Status of Young Children in Household Surveys. UN Department of Technical Cooperation for Development and Statistical Office, New York. 1986.

11. Matsvimbo N Nutritional Status of School Children and Associated Factors in Rupangwana Irrigation Scheme, Zibambwe. Unpublished MSc Thesis, University of Nairobi, Kenya. 1997.

12. Kennedy ET and B Cogill Income and Nutritional Effects of the Commercialisation of Agriculture in Southwestern Kenya. Research report, International Food Policy Research Institute, Washington, D.C. 1987; 9-59. 


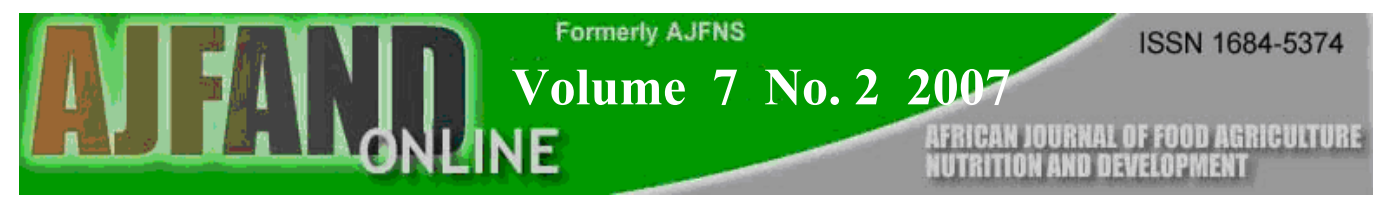

13. Biswas MR and P Pinstrup-Andersen Nutrition and Development. Oxford University Press, New York. 1985: 21-42.

14. Victoria VR, Vaughan JP, Kirkwood B, Martines JC and LB Barcelos Child Malnutrition and Land Ownership in Southern Brazil. Ecology of Food and Nutrition. 1986; $265-275$.

15. Haaga J, Mason J, Omoro FZ, Quinn V, Rafferty A, Test $K$ and $L$ Wasonga Child Malnutrition in Rural Kenya: A Geographical and Agricultural Classification. Ecology of Food and Nutrition. 1985; 18: 223 240.

16. Martorell R Nutrition and Health indicators: Suggestion for surveys of the standard of living in developing countries. LSMS Working Paper No. 13. 1985: 4-12.

17. Alderman $\mathbf{H}$ and M Garcia Poverty, Household Food Security and Nutrition in Rural Pakistan. Research report. International Food Policy Research Institute, Washington D.C. 1983: 50-64.

18. Government of Kenya Economic Survey 2000. Government Printers, Nairobi. 2000: $188-218$.

19. Smith LC and L Haddad Explaining Child Malnutrition in Developing Countries: A Cross-Country Analysis. Research Report III. IFPRI, Washington, D.C. 1999. 